This is the final peer-reviewed accepted manuscript of:

Kermani, H.A., Hosseini, M., Miti, A. et al. A colorimetric assay of DNA methyltransferase activity based on peroxidase mimicking of DNA template $\mathrm{Ag} / \mathrm{Pt}$ bimetallic nanoclusters. Anal Bioanal Chem 410, 4943-4952 (2018).

The final published version is available online at: https://doi.org/10.1007/s00216018-1143-2

Rights / License:

The terms and conditions for the reuse of this version of the manuscript are specified in the publishing policy. For all terms of use and more information see the publisher's website.

This item was downloaded from IRIS Università di Bologna (https://cris.unibo.it/)

When citing, please refer to the published version. 


\title{
A Colorimetric Assay of DNA Methyltransferase Activity Based on Peroxidase Mimicking of DNA Template Ag/Pt Bimetallic Nanoclusters
}

\author{
Hanie Ahmadzade Kermani • Morteza Hosseini • Andrea Miti • Mehdi dadmehr • Giampaolo \\ Zuccheri · Saman Hosseinkhani • Mohammad Reza Ganjali
}

H. Ahmadzade Kermani · M. Hosseini(*)

Department of Life Science Engineering, Faculty of New Sciences \& Technologies, University of Tehran, Tehran, Iran

E-mail address: smhosseini@khayam.ut.ac.ir

A. Miti - G. Zuccheri

Department of Pharmacy and Biotechnology and Interdepartmental Center for Industrial Research on Health Sciences and Technologies at the University of Bologna, the Nanoscience Institute of CNR, the National Interuniversity Consortium of Materials Science and Technology. Via Irnerio, 48 Bologna, Italy 40126.

M. dadmehr

Department of Biotechnology, Payeme Noor University, Tehran, Iran

S. Hosseinkhani

Department of Biochemistry, Tarbiat Modares University, Tehran, Iran

M. R. Ganjali

Center of Excellence in Electrochemistry, School of Chemistry, College of Science, University of Tehran, Tehran, Iran

Biosensor Research Center, Endocrinology and Metabolism Molecular-Cellular Sciences Institute, Tehran University of Medical Sciences, Tehran, Iran

Abstract DNA methylation catalyzed by DNA methyl transferase (MTase) is a significant epigenetic process for modulating gene expression. Abnormal levels of DNA MTaseenzyme have been regarded 
as a cancer biomarker or a sign of bacterial diseases. Here in, we developed a novel colorimetric method to assay M.SssI MTase activity employing peroxidase-like activity of DNA template $\mathrm{Ag} / \mathrm{Pt}$ NCs without using restriction enzymes. Based on inhibiting the peroxidase reaction occurred in the TMB- $\mathrm{H}_{2} \mathrm{O}_{2}$ system, in the presence of MTase, a highly sensitive and selective colorimetric biosensor was fabricated with a detection limit (LOD) of $0.05 \mathrm{U} / \mathrm{ml}$ and a linear range from $0.5 \mathrm{U} / \mathrm{ml}$ to 10 $\mathrm{U} / \mathrm{ml}$. The changes in absorption intensity were monitored to quantify the M.SssI activity. This strategy had a high selectivity over other proteins. Furthermore, it is also demonstrated that this method can be used for the evaluation and screening of inhibitors for DNA MTase.

Keywords: Ag/Pt nanoclusters $\cdot$ DNA methyltransferase $\cdot$ Colorimetric detection $\cdot$ Enzyme mimic

\section{Introduction}

DNA methylation, a common epigenetic modification of the genome, plays a critical role in both prokaryotes and eukaryotes [1]. It has received great attention due to its close relationship to various biological events, such as transcription, gene imprinting, chromatin structure, embryonic development, $\mathrm{X}$ chromosome inactivation in females and tumors [2, 3]. DNA methylation refers to methyl transfer from the S-adenosyl methionine (SAM) donor to cytosine or adenine residues in particular short palindromic sequences which achieved by the catalysis effect of DNA methyltransferases (MTase) [4, 5]. It has been demonstrated that alterations of MTases activity leads to aberrant DNA methylation patterns which are regarded as biomarkers of cancer in a variety of types of cancer such as gastric [6], lung [7], prostate [8], colon [9] and is associated with several genetic diseases $[10,11]$. Therefore, the detection and quantification of MTase activity has drawn much attention because of its significant role in both fundamental research and clinical applications. Up to now, some conventional methods for the detection of DNA methylation and assay of MTase activity have been developed, which include radioisotope labeling of [methyl-3H]-SAM [12], capillary electrophoresis [13], high performance liquid chromatography (HPLC) and mass spectroscopy [14], polymerase chain reaction (PCR) [15], SERS (Surface Enhanced Raman 
Spectroscopy) [16], western blotting [17] bisulfite treatment [18] and immune reaction [19]. However, all of them carry obvious drawbacks such as radioisotope labeled substrate, expensive antibodies, fluorescently labeled substrates, large-scale detection equipment, high operation cost, time-consuming sample preparation, insufficient sensitivity and so on. Thus, further efforts are needed in the development of rapid, sensitive, simple and economical methods for accurate DNA methylation detection and MTase activity assays. In order to improve the detection sensitivity and specificity, many new strategies for the detection of DNA MTase activity have been developed including electrochemical [20-22], chemiluminescent [23, 24], fluorescence methods [25-28], photoelectrochemistry [29] and colorimetric assays [30-33]. Among them the colorimetric strategy has received a widespread attention owing to the advantages of rapidity, simplicity, costeffectiveness, and especially, it may be easily read out by the naked eye without requiring expensive analytical instruments. Several colorimetric biosensors have been successfully developed for DNA MTase activity analysis. For example, Song et al. [34] and Liu et al. [35] proposed DNA MTase assay employing DNA-modified gold nanoparticles (AuNPs) dispersion and aggregation, Wu et al [36] have reported a colorimetric biosensor for DNA MTase detection based on MTase protection of the DNA-gold nanoparticles (AuNPs). Li et al. [37] developed a colorimetric method for detection of DNA MTase activity with the LOD of $6 \mathrm{U} / \mathrm{mL}$ based on methylation responsive DNAzyme. A labelfree colorimetric method was established based on methylation-blocked cascade amplification [38]. However, these methods were challenged with the limitation of using them due to complex reaction conditions of enzymes, the instability of the AuNPs and signal amplification system requirement. Thus, an assay with more stability and simplicity is still needed. It is well known that DNA has the capacity to be an efficient template for in situ fabrication of some nanomaterials such as metal NPs/NCs. These DNA-templated nanomaterials have shown unique properties such as facile synthesis, controllable size, and biocompatibility. Although DNA-templated Ag NCs and DNAtemplated $\mathrm{Au}$ NCs are reported as fluorescent probes in many bioassays [39-45] they show poor catalytic properties in the enzyme-mimicking activity [46]. Recently, Pt nanomaterials were found to 
be unique peroxidase enzyme mimetic $[47,48]$. Higuchi et al. established a colorimetric bioassay of thrombin based on a peroxidase-mimicking DNA-Pt complex [49]. Zheng et.al improved the previous work by developing a facile approach to produce DNA- Ag/Pt bimetallic nanoclusters with peroxidase-like catalytic activity for colorimetric detection of thrombin [46]. Then DNA- Ag/Pt NCs was applied in the colorimetric analysis of some analytes such as $\mathrm{Hg}^{2+}$ [50], L-Cys [51], the vascular endothelial growth factor (VEGF) [52]. In this article, the activity and inhibition of M.SssI MTase was explored in terms of the peroxidase-like activity of the DNA-Ag/Pt NCs due to its easy operation on unmodified oligonucleotides. M.SssI, a Prokaryotic DNA MTase, was employed in this work since it is an important model and experimental tool in DNA methylation study which shares the specificity of eukaryotic DNA MTase [53]. . We designed a C-rich ds-DNA as a synthesis template with internal CCGG palindromic site that is recognizable by M.SssI. It was found that DNA methylation by M.SssI can effectively inhibit the catalytic activity of DNA-Ag/Pt NCs selectively. Based on this finding, a colorimetric assay for DNA MTase activity detection was developed. The changes in blue color intensity were monitored to quantify the M.Sss I activity. A LOD of $0.05 \mathrm{U} / \mathrm{mL}$ was obtained with no amplification. Further study of the inhibition of atypical drug on the activity of M.SssI MTase was also investigated. . This method was designed without employing methylation specific restriction endonuclease beside MTase enzyme. Also, to the best of authors knowledge, it is the first DNA MTase colorimetric assay which does not use gold nanoparticles or any amplification strategy which are employed by previous reported assays $[36,38]$. This method has significant advantages including reproducibility, high sensitivity, good selectivity, rapidity and cost effectiveness.

\section{Experimental}

\section{Reagents and equipment}

CpG methyltransferase (M.SssI) and SAM were purchased from Thermo Scientific. According to the supplier, M.SssI is stored at $-20{ }^{\circ} \mathrm{C}$ in a buffer containing $10 \mathrm{mM}$ potassium phosphate( $\left.\mathrm{pH} 7.0\right), 400$ $\mathrm{mM} \mathrm{KCl}, 1 \mathrm{mM}$ DTT, $1 \mathrm{mM}$ EDTA, $0.2 \mathrm{mg} / \mathrm{ml} \mathrm{BSA}$ and $50 \%(\mathrm{v} / \mathrm{v})$ glycerol.AgNO 3 and sodium 
borohydride $\left(\mathrm{NaBH}_{4}\right)$ were purchased from Merck. 3, 3', 5, 5'-tetramethylbenzidine (TMB) and $\mathrm{K}_{2} \mathrm{PtCl}_{4}$ were purchased from Sigma Aldrich.

The base sequences of the oligonucleotides use in this work are listed in Supporting Information, Table S1. The oligonucleotides were synthesized and purified with PAGE by Shanghai Generay Biotech Co. The oligonucleotides were prepared with TE buffer (containing $1 \mathrm{MTris}-\mathrm{HCl}$ and 0.5 ml EDTA, $\mathrm{pH}$ 7.5). All chemicals were of analytical grade and used without further purification.

\section{Equipment}

Ultraviolet-Visible (UV-Vis) spectra were measured using Specord 250 spectrophotometer (Analytik Jena, Germany). Characterization of DNA-Ag/Pt NCs was determined by Transmission Electron Microscope (TEM) (Zeiss, EM10C, 80 KV, Germany) and Atomic Force Microscopy (Multimode 8, AFM, Bruker, U.S.A.). Energy dispersive X-ray (EDX) was recorded on MIRA III field emission scanning electron microscope (TESCAN, Czech Republic). The annealing process have been done with a Sprint thermal cycler (Themo Scientific Hybaid, USA).

\section{Preparation of DNA- Ag/Pt NCs}

The DNA-Ag/Pt NCs have been prepared according to the method described by Zheng et al. [46]. with a minor modification. Annealing reaction of two oligonucleotides was done by heating to $90{ }^{0} \mathrm{C}$ followed by slow cooling for 1 hour in a thermocycler. Briefly, $\mathrm{AgNO}_{3}$ solution $(50 \mu \mathrm{L}, 150 \mu \mathrm{M})$, $\mathrm{K}_{2} \mathrm{PtCl}_{4}$ solution $(120 \mu \mathrm{L}, 125 \mu \mathrm{M})$ and the templatesS1 and S2 DNA solution (300 $\mu \mathrm{L}, 2 \mu \mathrm{M}$ each) in phosphate buffer (10.0 mM, pH 7.4) were added together. After incubation for $30 \mathrm{~min}$ in the dark, freshly prepared $\mathrm{NaBH}_{4}$ solution $(40 \mu \mathrm{L}, 5 \mathrm{mM})$ was added immediately under vigorous shaking for 5 minutes in order to initiate the reduction reaction. Finally, the mixture was allowed to react at $37^{\circ} \mathrm{C}$ for $3 \mathrm{~h}$. The obtained DNA-Ag/Pt NCs can be stored at $4^{\circ} \mathrm{C}$ for 1 month.

\section{Gel electrophoresis analysis}


Gel electrophoresis was carried out to verify the hybridization of Cytosine rich DNA strand and the complementary strand. The experiment was performed in Phosphate buffer10.0 mM, (pH 7.4), same buffer used for the formation of the nanoclusters. All oligonucleotides were diluted to $4 \mu \mathrm{M}$ solution in buffer. $15 \mu 1$ of unmethylated (S1) or methylated (S3) sequence were mixed to $15 \mu 1$ of complementary strand (S2) to get $2 \mu \mathrm{M}$ final concentration. The mixtures were heated $5 \mathrm{~min}$ at $95^{\circ} \mathrm{C}$ and cooled in $1 \mathrm{~h}$ at $20{ }^{\circ} \mathrm{C}$ in a thermocycler. The samples were loaded on a polyacrylamide gel (10 $\%$ polyacrylamide in $1 \times$ TBE- $89 \mathrm{mM}$ Tris-boric acid, $\mathrm{pH} 8.0,0.002 \mathrm{M}$ EDTA $\mathrm{pH} 8.0$ ) to identify double stranded nanoclusters templates. The electrophoresis was carried in $1 \times \mathrm{TBE})$ at $40 \mathrm{~V}$ constant voltage for $2 \mathrm{~h}$ at room temperature. After staining with SYBR Gold nucleic acid gel stain solution (Invitrogen), the gel was imaged using a Gel Doc 1000 (Biorad). Gel images analysis have been performed using ImageJ software (imagej.nih.gov). For the analysis of the intensity of the bands, the profiles of gel lanes have been plotted after background subtraction. Peaks where selected and integrated to get the area. The ratio between the peak areas have then been calculated.

\section{Catalytic activity evaluation of DNA-Ag/Pt NCs}

Time-dependent absorbance change was monitored at $652 \mathrm{~nm}$ at $25^{\circ} \mathrm{C}$ (Fig. S1). In order to detect the peroxidase-like activity of DNA-Ag/Pt NCs in a typical colorimetric reaction, $10 \mu \mathrm{l}$ of DNAAg/Pt NCs solution was added into $200 \mathrm{mM}$ acetate buffer at $\mathrm{pH} 4.0 .20 \mu \mathrm{H}_{2} \mathrm{O}_{2} 0.5 \mathrm{M}$ and $40 \mu \mathrm{l}$ TMB 4 mM was added into above solution to initiate color reactions, which were monitored with the absorption at $652 \mathrm{~nm}$. All the experiments were repeated three times for reproducibility.

\section{M.SssI activity detection}

To assay the M.SssI MTase activity, different concentrations of M.SssI with SAM substrate and buffer solution $(10 \mathrm{mM}$ potassium phosphate $\mathrm{pH}$ 7.0, $400 \mathrm{mM} \mathrm{KCl,} 1 \mathrm{mM}$ DTT, $1 \mathrm{mM}$ EDTA, 0.2 $\mathrm{mg} / \mathrm{ml} \mathrm{BSA}$ and 50\% v/v glycerol) were added to a constant amount of DNA/Ag NCs solution. Then the mixtures was incubated at $37{ }^{\circ} \mathrm{C}$ for 30 min, Afterwards, $20 \mu \mathrm{L}$ of $\mathrm{H}_{2} \mathrm{O}_{2}(0.5 \mathrm{M})$ and $40 \mu \mathrm{L}$ of 
TMB (4 mM) were added. Finally, the mixture was incubated at $37^{\circ} \mathrm{C}$ for $15 \mathrm{~min}$ and absorbance values were recorded by UV-Vis spectrophotometer at $652 \mathrm{~nm}$. Further color production of $\mathrm{Ag} / \mathrm{Pt}$ NCs with methylated oligonucleotide and unmethylated oligonucleotide DNA templates have been compared which proved the methyl group effect on peroxidase like activity of nanoclusters.

\section{Selectivity and inhibition of M.SssI activity}

BSA and Dpn I were selected as the potential interfering proteins. The selectivity experiments were conducted in the same way as the M.SssI activity detection procedure with $5 \mathrm{U} \mathrm{mL}^{-1} \mathrm{Dpn} \mathrm{I}$ and $1 \mu \mathrm{M}$ BSA. Gentamicin inhibition effect on M.SssI MTase activity was evaluated by incubation of different concentration of Gentamicin with DNA-Ag/Pt NCs and M.SssI MTase (10U/ml), SAM and buffer solution for $15 \mathrm{~min}$ at $37{ }^{\circ} \mathrm{C}$. After the addition of $\mathrm{H}_{2} \mathrm{O}_{2}$ and $\mathrm{TMB}$, the absorption at $652 \mathrm{~nm}$ was recorded.

\section{Results and discussion}

\section{Principle of colorimetric M.SssI MTase activity detection}

In this work, we present a facile strategy for the assay of M.SssI activity and the detection of DNA methylation based on DNA-Ag/Pt peroxidase-like activity of DNA-Ag/Pt NCs. The assay strategy is shown in Scheme 1. A cytosine rich single stranded DNA and its complementary were designed for this assay, based on previous works [46] with a slight modification. The subsequence 5'-CCGG-3' was inserted inside, which is specifically recognized by M.SssI. After hybridization, the DNA duplex can serve as a template for $\mathrm{Ag} / \mathrm{Pt} \mathrm{NCs}$ formation with following mechanism. $\mathrm{Ag}(\mathrm{I})$ has strong affinity to cytosine base and interact with C-rich DNA and form Ag NCs after being reduced with $\mathrm{NaBH}_{4}$. Then because of galvanic replacement reaction between $\operatorname{Ag}(0)$ and $\mathrm{Pt}(\mathrm{II}), \mathrm{Pt}(0)$ growth would be initiated on the surface of Ag NCs and continue due to reduction with $\mathrm{NaBH}_{4}$. Since the peroxidaselike activity of DNA-Ag/PtNCs is attributed to deposition of PtNCs onto AgNCs, AgNCs are considered to support for PtNCs deposition. Indeed, PtNCs could not be formed without presence of 
AgNCs [46]. It has been known for many years that silver has high affinity for binding to cytosine bases compared to the other bases. Methyl cytosine plays an intermediate role between cytosine and thymine, which has a low affinity for silver $[54,55]$. As reported in the previous studies, addition of methylated cytosines in the DNA sequence resulted to reduction of the fluorescence emission of DNA AgNCs in a linear range $[39,40]$. This could be originated from the possible changes in orientation, intercalation or interaction of $\mathrm{Ag}$ NCs with cytosine bases, which lead to formation of new silver atom bond lengths or angles. Figure S2 exhibits the fluorescence emission of the DNA/Ag NCs with methylated and unmethylated DNA templates. The fluorescence peak of Ag NCs decreased when methylated DNA was used as the nanocluster template and Ag/Pt NCs did not show any fluorescence. Thus, it can be concluded that formation of AgNCs is affected by the methylation of cytosines and consequently the deposition of PtNCs on AgNCs may be changed.

DNA-Ag/Pt NCs could catalyze the oxidation of TMB by $\mathrm{H}_{2} \mathrm{O}_{2}$, which produces a bright blue product and results in an intense absorption peak at $652 \mathrm{~nm}$, which is the characteristic peak of oxidized TMB. Subsequently, in the presence of M.SssI MTase and SAM, the DNA hybrid was methylated resulting in decrease in DNA/Ag-Pt NCs catalytic activity. Therefore, MTase activity could be quantified by monitoring the change in produced blue color intensity of solutions. Since methylation of DNA can be restrained in the presence of inhibitors, so this assay could also be used to screen M.SssI MTase inhibitors.

\section{Scheme 1}

\section{Characterization of synthesized Ag/Pt NCs}

A typical energy-dispersive X-ray (EDX) spectrum of DNA-Ag/Pt NCs is shown in Fig 1A, where elemental Ag and $\mathrm{Pt}$ is clearly detected, indicating the $\mathrm{Ag} / \mathrm{Pt}$ bimetallic NCs have been formed successfully. The size and morphology of the obtained nanoclusters were characterized by using TEM (Fig 1B and C). The DNA-Ag/Pt NCs were about $2 \mathrm{~nm}$ in size, roughly spherical and well distributed. 
The results found in AFM imaging (Fig. 1D and F) matched those from TEM. TEM and AFM imaging do not show significantly different results on the nanoclusters obtained from methylated and unmethylted oligonucleotides, although, it could be noted that for methylated DNA template a slightly bigger percentage of nanoclusters are smaller than $1,5 \mathrm{~nm}$, obviously paired to a lower percentage of nanoclusters in bigger size ranges compared to unmethylated DNA-Ag/Pt NCs (Fig 1E). Even if this could be weakly related to the differences in catalytic activity, we conclude that nanoclusters are equally formed on both the methylated and unmethylated template DNAs and in general no strong differences in shape and dimensions can be appreciated.

Fig. 1

\section{The feasibility of the designed system}

To demonstrate how practical, the proposed strategy is to detect DNA methylation, some experiments were conducted. The specific sequence S1 and the methylated one S3 have been annealed to complementary sequence S2 to form double stranded DNA (as verified by gel electrophoresis (Fig. 2A). Nanoclusters formation was performed on double stranded DNA S1/S2 and S3/S2 and the DNA$\mathrm{Ag} / \mathrm{Pt}$ NCs were tested for their catalytic activity (Fig.2B). These results showed that both methylated and unmethylated DNA scaffold provide suitable condition for nanoclusters formation, but as observed in the case of single stranded DNA, the presence of methyl groups on cytosine residues reduced the catalytic activity of $\mathrm{Ag} / \mathrm{Pt} \mathrm{NCs}$. This experiment is a further proof that the described strategy is suitable for a colorimetric assay of MTase activity.

Fig. 2

Methyltransferase activity assay 
To further investigate the analytical performance of the designed method for M.SssI activity analysis, after choosing the optimal conditions, DNA-Ag/Pt NCs were firstly incubated with M.SssI at various concentrations then the colorimetric reaction described in section "M.SssI activity detection" were carried out, afterward the absorption spectrums were recorded with increase of M.SssI from 0.05 to $15 \mathrm{U} / \mathrm{ml}$. As seen in Fig 3A (left to right), the color changed from blue to colorless with the increasing of the M.SssI concentrations. The corresponding UV vis absorption spectra were represented in Fig. 3B. As the concentration of M.SssI MTase increased, the absorption intensity decreased. Designed strategy showed a linear correlation with the logarithm of M.SssI enzyme concentration in the range of 0.5-10 unit/Ml M.SssI with a correlation coefficient of 0.996 and the LOD was 0.05 unit/mL which is comparable with recent reports [31] (Fig. 3C).

\section{Fig. 3}

\section{M.SssI methyltransferase inhibition assay}

To check the validity of our method in screening the inhibitors of M.SssI, we have employed Gentamicin as an inhibitor model [56]. We have evaluated the inhibitor effects by incubating DNAAg/Pt NCs and M.SssI MTase and SAM with different doses of Gentamicin (Fig. 4). The activity of the M.SssI decrease with the increasing concentration of Gentamicin showing a dose dependent inhibition. The $\mathrm{IC}_{50}$ value is the inhibitor concentration required to reduce enzyme activity by $50 \%$. In this study $\mathrm{IC}_{50}$ has been found to be $3.1 \mu \mathrm{M}$ which indicates that this is a promising method to screen the inhibitor effects of drugs on MTase [56, 57].

\section{Fig. 4}

\section{Selectivity study}

To evaluate the selectivity of the proposed assay, we investigated the effect of BSA and Dpn I as nonspecific enzymes. BSA is an irrelevant protein and DpnI is an enzyme which can only recognize the sequence (5'-GATC-3') in ds DNA. As shown in Figure5, 5 U/ml M.SssI could induce a remarkable 
decrease of absorbance of DNA-Ag/Pt NCs solution. On the other hand, other proteins at concentration of $1 \mu \mathrm{M}$ for BSA and 5U/ml for DpnI had no obvious effects on absorbance, indicating that our system could be a potential colorimetric tool for sensitive detection of M.SssI DNA methylransferase activity.

\section{Fig. 5}

\section{Conclusion}

In summary, we have successfully developed a novel Ag/Pt NCs based colorimetric strategy for detecting MTase activity with high sensitivity and selectivity. To the best of our knowledge, it is the first DNA MTase colorimetric assay apart from the using of gold nanoparticles or amplification strategies. We attempted to characterize the DNA-Ag/Pt NCs and presented novel approach for better understanding of mechanism and the possible effects of methylation. The assay was designed without employing the endonuclease enzyme and any amplification step. The preparation of the DNA Ag/ Pt NCs probe including hybridization and reduction steps is facile, low-cost and accessible to numerous laboratories. Moreover, there is no requirement of additional functionalization of DNA-templated nanoclusters with biomolecules and exploiting complex operations such as separation, precipitation or washing. We have evaluated further inhibitor screening capability of the proposed method which can be extended to screen another suitable inhibitors as anticancer and antimicrobial agent.

\section{Acknowledgments}

The authors thank the research Council of University of Tehran (Grant 28645/01/02) for financial support of this work.

\section{Compliance with ethical standards}

Conflict of interest The authors declare that they have no competing interests. 


\section{References}

1 Reik W, Dean W, Walter J. Epigenetic Reprogramming in Mammalian Development. Science 2001;293:1089-1093.

2 Wu SC, Zhang Y. Active DNA demethylation: many roads lead to Rome. Nat. Rev. Mol. Cell Biol. 2010;11:607-620.

3 Lopez-serra P, Esteller M. DNA methylation-associated silencing of tumor-suppressor microRNAs in cancer. Oncogene 2012;31:1609-1622.

4 Jeltsch A. Beyond Watson and Crick: DNA methylation and molecular enzymology of DNA methyltransferases. Chembiochem 2002;3:274-293.

5 Turek-plewa J, Jagodzinski PP. The role of mammalian DNA methyltransferases in the regulation of gene expression. Cell. Mol. Biol. Lett. 2005;10:631-647.

6 Mutze K, Langer R, Schumacher F, Becker K, Ott K, Novotny A, Hapfelmeier A, Höfler H, Keller G. DNA methyltransferase 1 as a predictive biomarker and potential therapeutic target for chemotherapy in gastric cancer. Europ. J. Cancer 2011:47:1817-1825.

7 Belinsky SA, Nikula KJ, Baylin SB, Issa JP. Increased cytosine DNA-methyltransferase activity is target-cell-specific and an early event in lung cancer. Proceed. National Academy of Sci. 1996;93:4045-4050. 
8 Kobayashi Y, Absher DM, Gulzar ZG, Young SR, Mckenney JK, Peehl DM, Brooks JD, Myers RM, Sherlock G. DNA methylation profiling reveals novel biomarkers and important roles for DNA methyltransferases in prostate cancer. Genome Res. 2011;21:1017-1027.

9 Baylin SB Herman JG. DNA hypermethylation in tumorigenesis: epigenetics joins genetics. Trends in Genetics 2000;16:168-174.

10 Das PM, Singal R. DNA Methylation and Cancer. J. Clinical Oncolog. 2004;22:4632-4642.

11 Lyko F, Brown R. DNA Methyltransferase Inhibitors and the Development of Epigenetic Cancer Therapies. JNCI 2005;97:1498-1506.

12 Myrnes B, Norstrand K, Giercksky KE, Sjunneskog C, Krokan H. A simplified assay for O 6 methylguanine-DNA methyltransferase activity and its application to human neoplastic and nonneoplastic tissues. Carcinogenesis 1984;5:1061-1064.

13 Zou D, Zhang D., Liu S, Zhao B, Wang H. Interplay of Binding Stoichiometry and Recognition Specificity for the Interaction of MBD2b Protein and Methylated DNA Revealed by Affinity Capillary Electrophoresis Coupled with Laser-Induced Fluorescence Analysis. Anal. Chem. 2014;86:1775-1782.

14 Li X, Franke AA. High-throughput and cost-effective global DNA methylation assay by liquid chromatography-mass spectrometry. Anal. Chim. Acta 2011;703:58-63.

15 Lyko F, Ramsahoye BH, Jaenisch R. Development: DNA methylation in Drosophila melanogaster. Nature 2000;408:538-540.

$16 \mathrm{Hu}$ J, Zhang CY. Single base extension reaction-based surface enhanced Raman spectroscopy for DNA methylation assay. Biosens. Bioelectron. 2012;31:451-457.

17 Boye E, Marinus MG, Løbner-olesen A. Quantitation of Dam methyltransferase in Escherichia coli. J. Bacteriol. 1992;174:1682-1685.

18 Wan Y, Wang Y, Luo J, Lu Z. Bisulfite modification of immobilized DNAs for methylation detection. Biosens. Bioelectron. 2007;22:2415-2421. 
19 Yin H, Zhou Y, Xu Z, Wang M, Ai S. Ultrasensitive electrochemical immunoassay for DNA methyltransferase activity and inhibitor screening based on methyl binding domain protein of MeCP2 and enzymatic signal amplification. Biosens Bioelectron. 2013;49:39-45.

20 Yang Z, Wang F, Wang M, Yin H, AI S. A novel signal-on strategy for M.SssI methyltransfease activity analysis and inhibitor screening based on photoelectrochemical immunosensor. Biosens Bioelectron. 2015;66:109-114.

21 Deng H, Yang X, Yeo SPX, Gao Z. Highly Sensitive Electrochemical Methyltransferase Activity Assay. Anal. Chem. 2014;86:2117-2123.

22 Zhang L, Liu Y, Li Y, Zhao Y, Wei W, Liu S. Sensitive electrochemical assaying of DNA methyltransferase activity based on mimic-hybridization chain reaction amplified strategy. Anal. Chim. Acta 2016;933:75-81.

23 Zhao HF, Liang RP, Wang JW, Qiu JD. One-pot synthesis of GO/AgNPs/luminol composites with electrochemiluminescence activity for sensitive detection of DNA methyltransferase activity. Biosens. Bioelectron. 2015;63:458-464.

24 Zeng Y. P, Hu J, Long Y, Zhang CY. Sensitive Detection of DNA Methyltransferase Using Hairpin Probe-Based Primer Generation Rolling Circle Amplification-Induced Chemiluminescence. Anal. Chem. 2013;85:6143-6150.

25 Kermani H. A, Hosseini M, Dadmehr M. Hosseinkhani S, Ganjali MR. DNA methyltransferase activity detection based on graphene quantum dots using fluorescence and fluorescence anisotropy. Sens. Actuators B 2017;241:217-223.

26 Ji L, Cai Z, Qian Y, Wu P. Zhang H, Cai C. Highly sensitive methyltransferase activity assay and inhibitor screening based on fluorescence quenching of graphene oxide integrated with the sitespecific cleavage of restriction endonuclease. Chem. Commun. 2014;50:10691-10694.

27 Ouyang X, Liu J, Li J, Yang R. A carbon nanoparticle-based low-background biosensing platform for sensitive and label-free fluorescent assay of DNA methylation. Chem. Commun. (Camb) 2012;48:88-90. 
28 Gao C, Li H, Liu Y, Wei W, Zhang Y, Liu S. Label-free fluorescence detection of DNA methylation and methyltransferase activity based on restriction endonuclease HpaII and exonuclease III. Analyst 2014;139:6387-6392.

29 Wang H, Liu P, Jiang W, Li X, Yin H, Ai S. Photoelectrochemical immunosensing platform for M. SssI methyltransferase activity analysis and inhibitor screening based on g-C3N4 and CdS quantum dots. Sens. Actuators B 2017;244:458-465.

30 Liu P, Zhang K, Zhang R, Yin H, Zhou Y, AI S. A colorimetric assay of DNA methyltransferase activity based on the keypad lock of duplex DNA modified meso-SiO2@Fe3O4. Anal. Chim. Acta 2016;920:80-85.

31 Li ZM. Zhong ZH, Liang RP, Qiu JD. The colorimetric assay of DNA methyltransferase activity based on strand displacement amplification. Sens. Actuators B 2017;238:626-632.

32 Cui W, Wang L, Xu X, Wang Y, Jiang W. A loop-mediated cascade amplification strategy for highly sensitive detection of DNA methyltransferase activity. Sens. Actuators B 2017;244:599605.

33 Su F, Wang L, Sun Y, Liu C, Duan X, Li Z. Highly sensitive detection of CpG methylation in genomic DNA by AuNP-based colorimetric assay with ligase chain reaction. Chem. Commun. (Camb) 2015;51:3371-3374.

34 Song G, Chen C, Ren J, Qu X. A Simple Universal Colorimetric Assay for Endonuclease/Methyltransferase Activity and Inhibition Based on an Enzyme-Responsive Nanoparticle System. ACS Nano 2009;3:1183-1189.

35 Liu T. Zhao J. Zhang D, Li G. Novel Method to Detect DNA Methylation Using Gold Nanoparticles Coupled with Enzyme-Linkage Reactions. Anal. Chem. 2010;82:229-233.

$36 \mathrm{Wu}$ Z, Wu ZK, Tang H, Tang LJ, Jiang JH. Activity-Based DNA-Gold Nanoparticle Probe as Colorimetric Biosensor for DNA Methyltransferase/Glycosylase Assay. Anal. Chem. 2013;85:4376-4383. 
$37 \mathrm{Li} \mathrm{W,} \mathrm{Liu} \mathrm{Z,} \mathrm{Lin} \mathrm{H,} \mathrm{Nie} \mathrm{Z,} \mathrm{Chen} \mathrm{J,} \mathrm{Xu} \mathrm{X,} \mathrm{Yao} \mathrm{S.} \mathrm{Label-Free} \mathrm{Colorimetric} \mathrm{Assay} \mathrm{for}$ Methyltransferase Activity Based on a Novel Methylation-Responsive DNAzyme Strategy. Anal. Chem. 2010;82:1935-1941.

38 Zhao Y, Chen F, Lin M, Fan C. A methylation-blocked cascade amplification strategy for labelfree colorimetric detection of DNA methyltransferase activity. Biosens. Bioelectron. 2014;54:565-570.

39 Kermani HA, Hosseini M, Dadmehr M, Ganjali MR. Rapid restriction enzyme free detection of DNA methyltransferase activity based on DNA-templated silver nanoclusters. Anal. Bioanal. Chem. 2016;408:4311-4318.

40 Dadmehr M, Hosseini M, Hosseinkhani S, Ganjali MR, Sheikhnejad R. Label free colorimetric and fluorimetric direct detection of methylated DNA based on silver nanoclusters for cancer early diagnosis. Biosens. Bioelectron. 2015;73:108-113.

41 Qiu X, Wang P, Cao Z. Hybridization chain reaction modulated DNA-hosted silver nanoclusters for fluorescent identification of single nucleotide polymorphisms in the let-7 miRNA family. Biosens Bioelectron. 2014;60:351-357.

42 Zhang S, Wang K, Li K. B, Shi W, Jia WP, Chen X, Sun T, Han DM. A DNA-stabilized silver nanoclusters/graphene oxide-based platform for the sensitive detection of DNA through hybridization chain reaction. Biosens. Bioelectron. 2017;91:374-379.

43 Shokri E, Hosseini M, Faridbod F, Rahaie M. Synthesis and Assessment of DNA/Silver Nanoclusters Probes for Optimal and Selective Detection of Tristeza Virus Mild Strains. J. Fluorescence 2016;26:1795-1803.

44 Shokri E, Hosseini M, Faridbod F, Rahaie M. Rapid pre-symptomatic recognition of tristeza viral RNA by a novel fluorescent self-dimerized DNA-silver nanocluster probe. RSC Adv. 2016;6:99437-99443. 
45 Liu W, Lai H, Huang R, Zhao C, Wang Y, Weng X, Zhou X. DNA methyltransferase activity detection based on fluorescent silver nanocluster hairpin-shaped DNA probe with 5'-C-rich/Grich-3’ tails. Biosens. Bioelectron. 2015;68:736-740.

46 Zheng C, Zheng A. X, Liu B, Zhang X. L, He Y, Li J, Yang HH, Chen G. One-pot synthesized DNA-templated Ag/Pt bimetallic nanoclusters as peroxidase mimics for colorimetric detection of thrombin. Chem. Commun. 2014;50:13103-13106.

47 You H, Peng Z, Wu J, Yang H. Lattice contracted AgPt nanoparticles. Chem. Commun. 2011;47:12595-12597.

48 Gao Z, Xu M, Hou L, Chen G, Tang D. Irregular-shaped platinum nanoparticles as peroxidase mimics for highly efficient colorimetric immunoassay. Anal. Chim. Acta 2013;776:79-86.

49 Higuchi A, Siao YD, Yang ST, Hsieh PV, Fukushima H, Chang Y, Ruaan RC, Chen WY. Preparation of a DNA Aptamer-Pt Complex and Its Use in the Colorimetric Sensing of Thrombin and Anti-Thrombin Antibodies. Anal. Chem. 2008;80:6580-6586.

50 Wu LL, Wang LY, Xie ZJ, Xue F, Peng CF. Colorimetric detection of Hg2+ based on inhibiting the peroxidase-like activity of DNA-Ag/Pt nanoclusters. RSC Adv. 2016;6:75384-75389.

51 Wu LL, Wang LY, Xie ZJ, Pan N, Peng CF. Colorimetric assay of l-cysteine based on peroxidasemimicking DNA-Ag/Pt nanoclusters. Sens. Actuators B 2016;235:110-116.

$52 \mathrm{Fu}$ XM, Liu ZJ, Cai SX, Zhao YP, Wu DZ, Li CY, Chen JH. Electrochemical aptasensor for the detection of vascular endothelial growth factor (VEGF) based on DNA-templated $\mathrm{Ag} / \mathrm{Pt}$ bimetallic nanoclusters. Chinese Chem. Lett. 2016;27:920-926.

53 Stier I, Kiss A. Cytosine-to-Uracil Deamination by SssI DNA Methyltransferase. PloS one. 2013;8(10):e79003.

54 New SY, Lee ST, Su XD. DNA-templated silver nanoclusters: structural correlation and fluorescence modulation. Nanoscale 2016;8:17729-17746.

55 An H, JIN B. Prospects of nanoparticle-DNA binding and its implications in medical biotechnology. Biotechnol. Adv. 2012;30:1721-1732. 
56 Zhang Y, Xu WJ, Zeng YP, Zhang CY. Sensitive detection of DNA methyltransferase activity by transcription-mediated duplex-specific nuclease-assisted cyclic signal amplification. Chem. Commun. 2015;51:13968-13971.

57 Xing XW, Tang F. Wu J. Chu JM. Feng YQ. Zhou X, Yuan BF. Sensitive Detection of DNA Methyltransferase Activity Based on Exonuclease-Mediated Target Recycling. Anal. Chem. 2014;86:11269-11274.

\section{Figure caption:}

Scheme 1 Schematic illustration of the proposed colorimetric assay for the detection of M.SssI MTase activity

Fig.1 (A) EDX spectrum of DNA-Ag/Pt NCs. TEM images of synthesized Ag/Pt NCs by unmethylated (B) and methylated (C). AFM images of synthesized Ag/Pt NCs by unmethylated (D) and methylated (E) DNA template. (F) DNA and size distribution histogram of $\mathrm{Ag} / \mathrm{Pt} \mathrm{NCs}$ of unmethylated and methylated DNA.

Fig. 2 (A) Gel electrophoresis analysis of double stranded template for Ag/Pt NCs formation. Lane 1: S1; Lane 2: S1/S2; Lane 3: S3/S2. (B) Spectrum of absorbance measured at $652 \mathrm{~nm}$ showing the catalytic activity of double strande

Fig. 3 Changes in blue color intensity (A) Photograph and (B) Absorption spectra in the presence of different concentration of M.SssI. The curves from bottom to top were obtained with different 
concentration 15, 10, 7.5, 5, 2, 1.5, 1, 0.5, 0.25, 0.05 and $0 \mathrm{U} / \mathrm{ml} \mathrm{M.SssI.} \mathrm{(C)} \mathrm{The} \mathrm{relationship} \mathrm{between}$ the absorbtion intensity at $652 \mathrm{~nm}$ and the concentration of M.SssI MTase. The inset shows linear correlation between absorption intensity at $652 \mathrm{~nm}$ and the logarithm of M.SssI concentration in the range of 0.5 to $10 \mathrm{U} / \mathrm{ml}$. Error bars show the standard deviation of 3 experiments.

Fig. 4 Inhibitory effect of Gentamicin on the activity of M.SssI. The concentration of M.SssI is 5 $\mathrm{U} / \mathrm{ml}$. ( $\mathrm{A}_{0}$ is absorbance intensity of $\mathrm{Ag} / \mathrm{Pt} \mathrm{NCs} \mathrm{incubated} \mathrm{with} 5 \mathrm{U} / \mathrm{ml} \mathrm{M.SssI}$ and $\mathrm{A}$ is the absorbance intensity of AgNCs incubated with $5 \mathrm{U} / \mathrm{ml} \mathrm{M.SssI} \mathrm{with} \mathrm{different} \mathrm{concentration} \mathrm{of} \mathrm{Gentamicin:} \mathrm{0,} \mathrm{2,}$ 4, 6, 8, $10 \mu \mathrm{M})$. Error bars show the standard deviation of 3 experiments.

Fig. 5 Absorption response of the assay for different proteins: M.SssI, BSA, Dpn I. Error bars show the standard deviation of 3 experiments. 


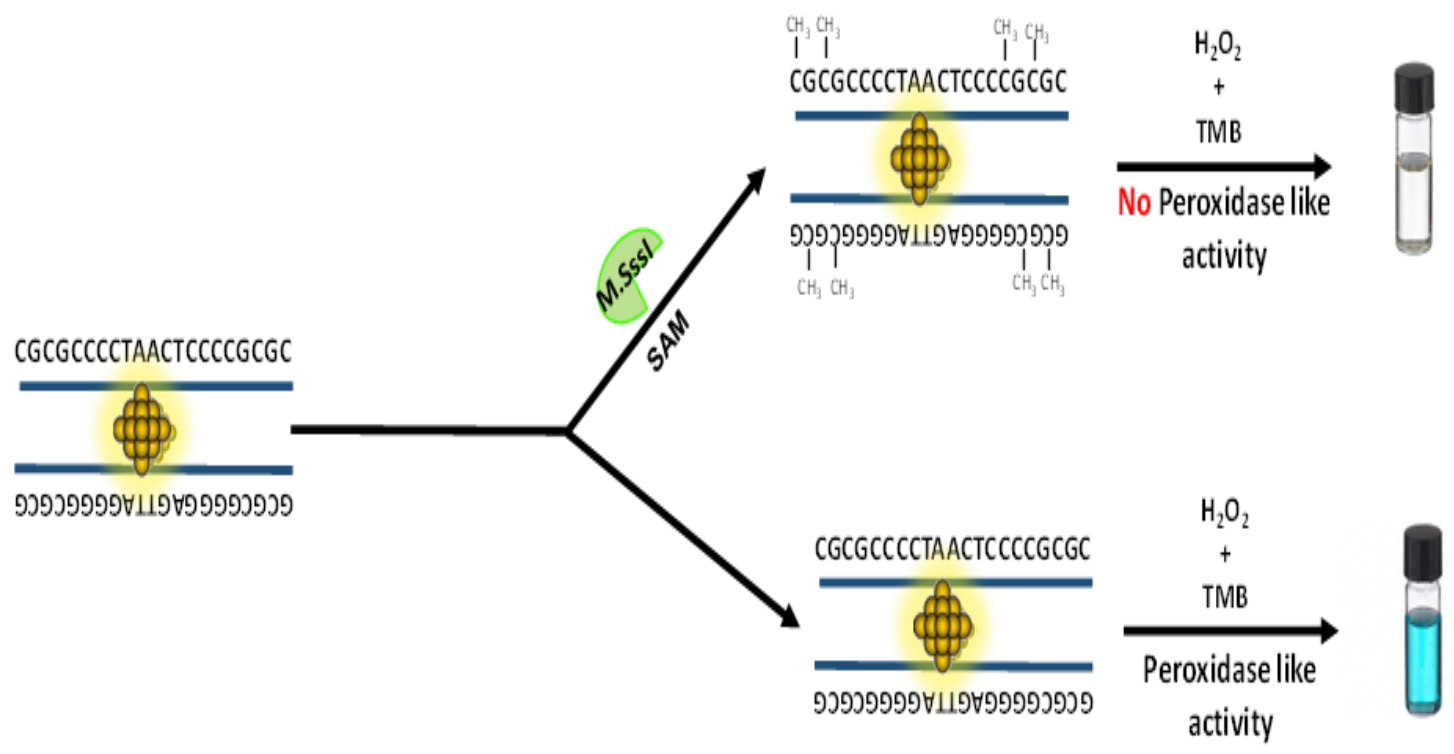

Scheme 1 


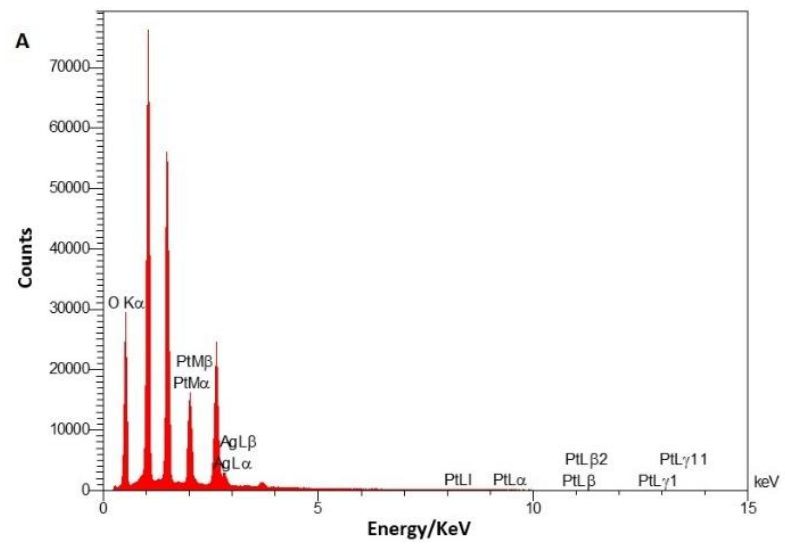

B

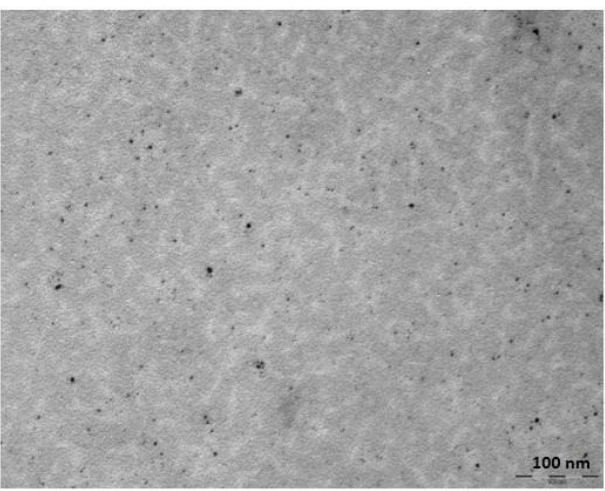

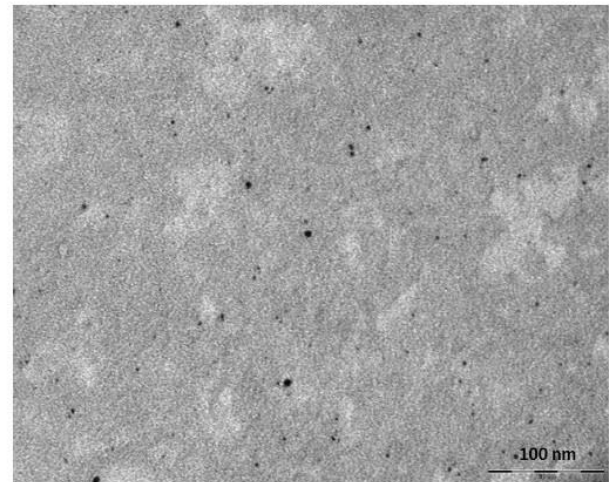




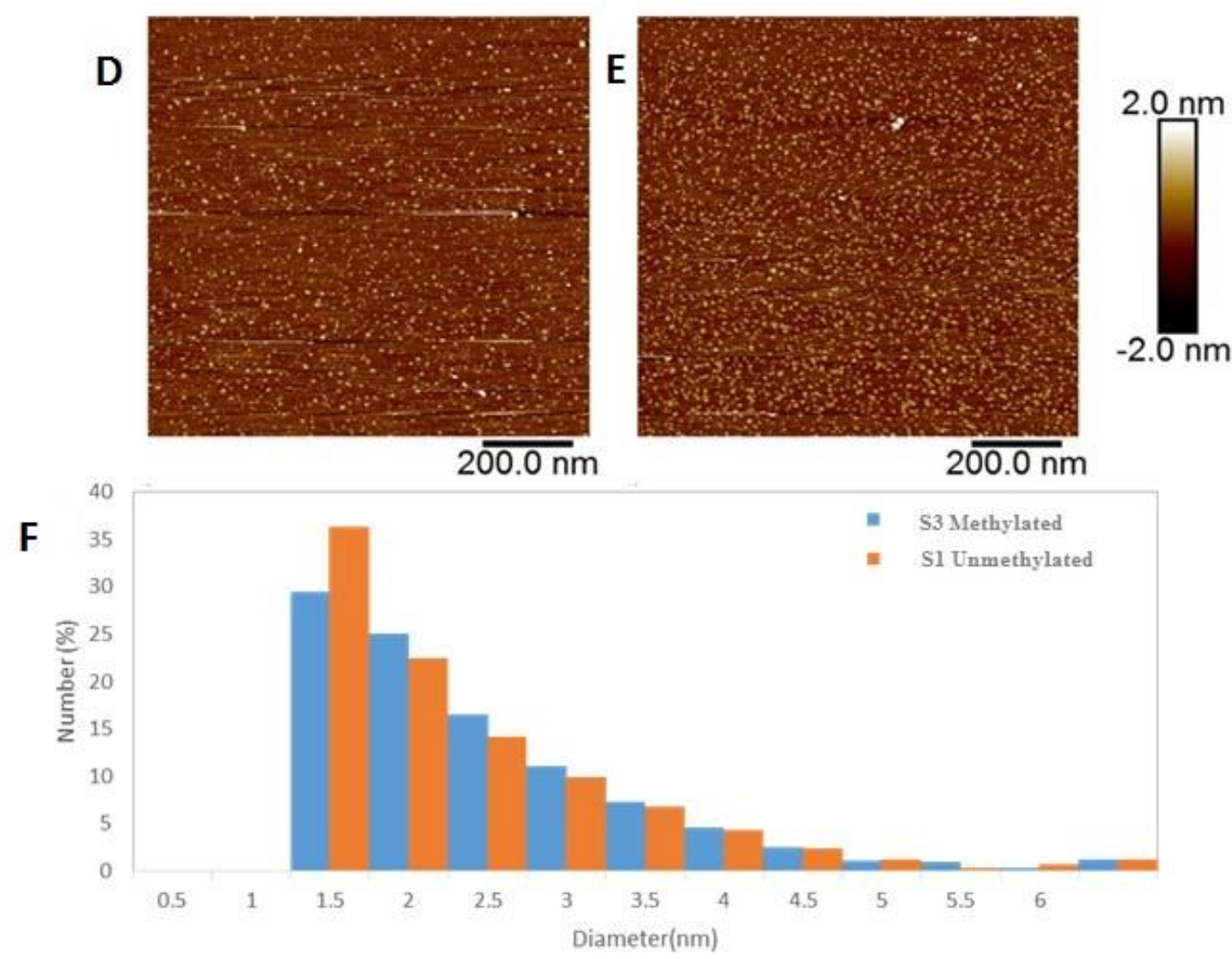

Fig. 1

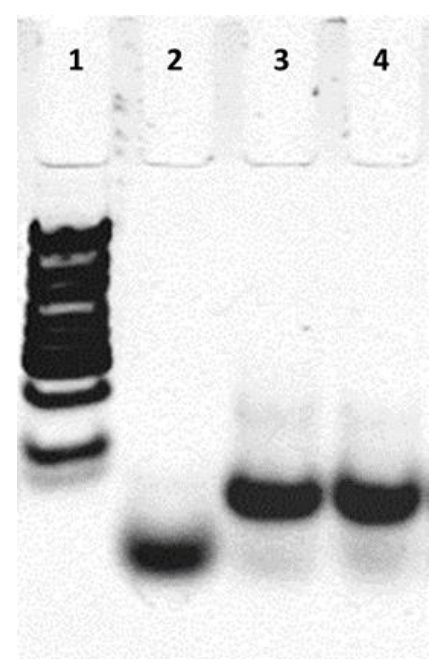

(A) 


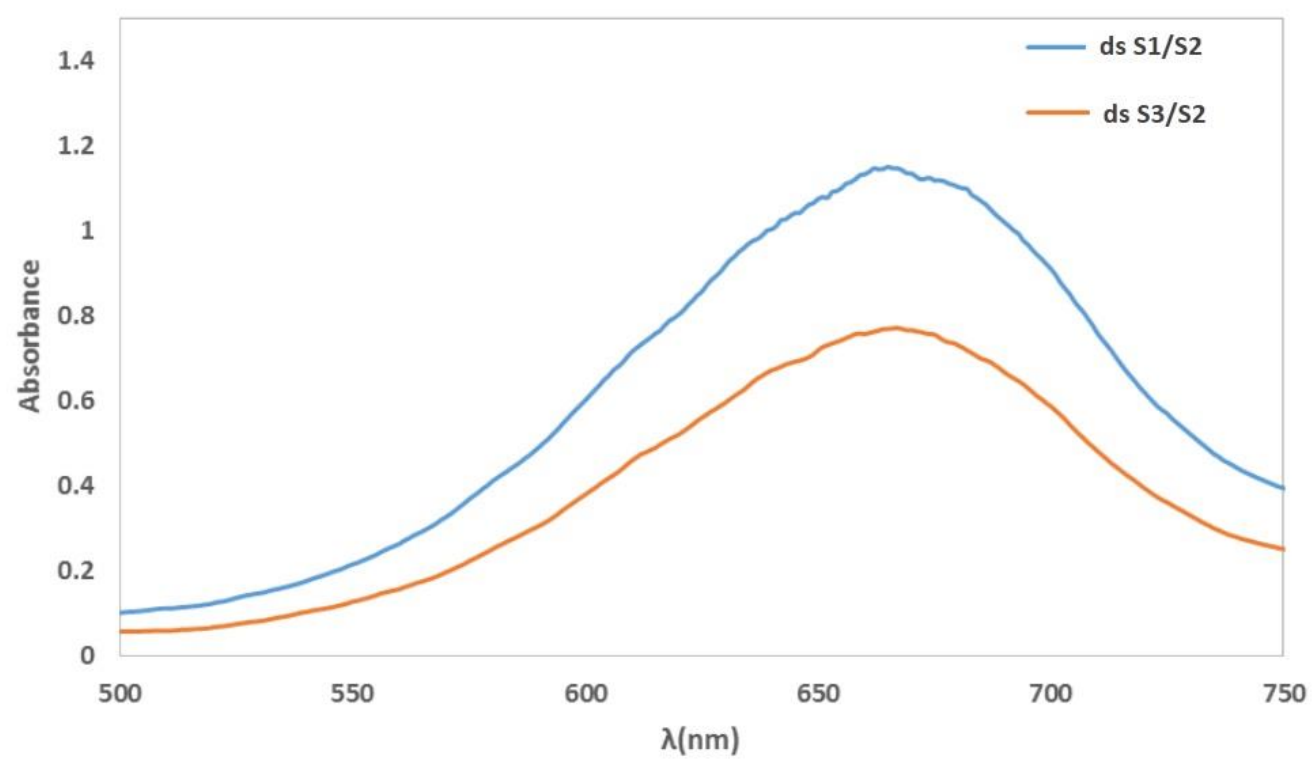

(B)

Fig. 2

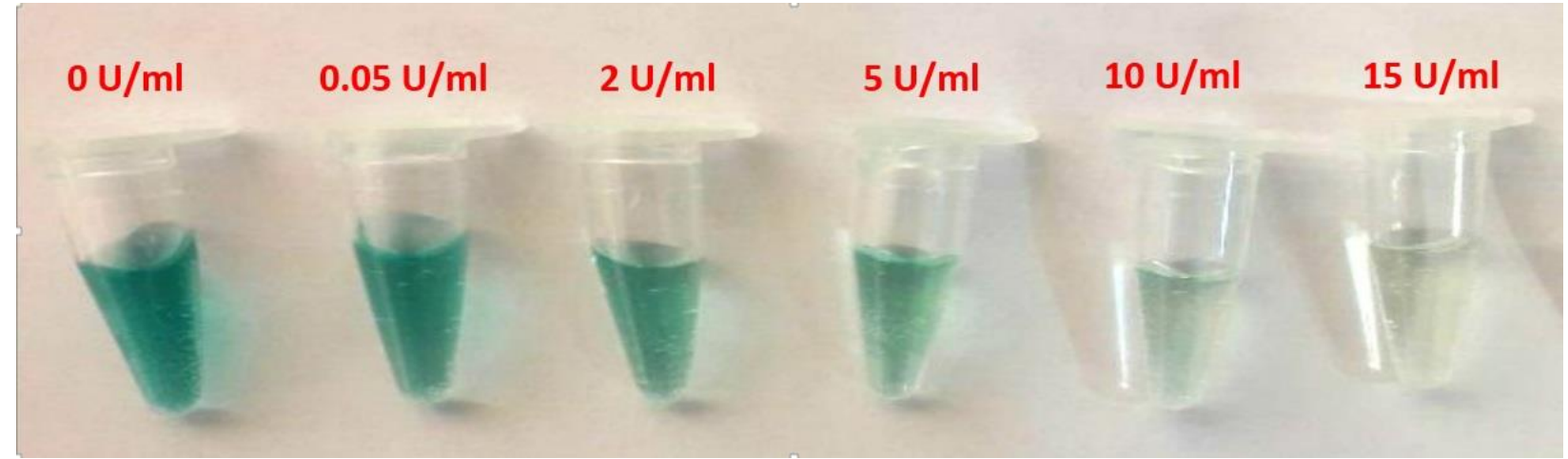

(A) 


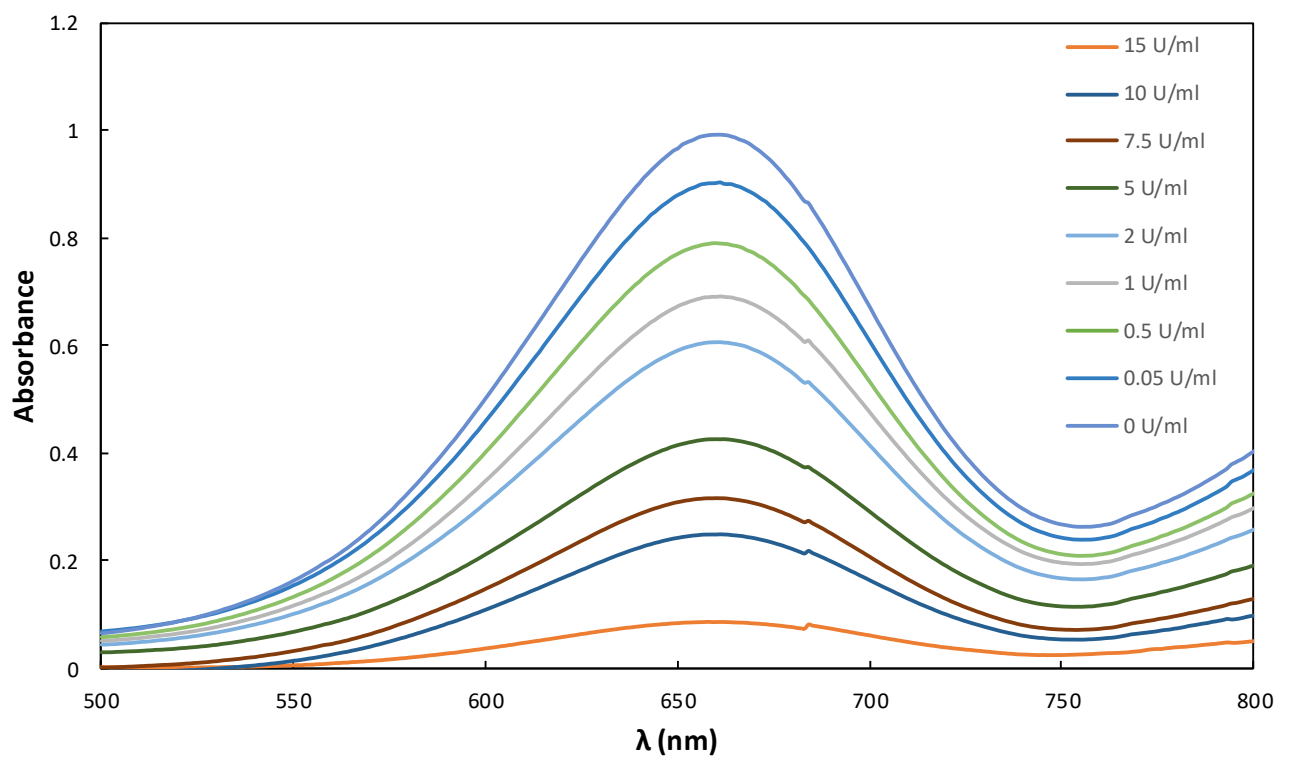

(B)

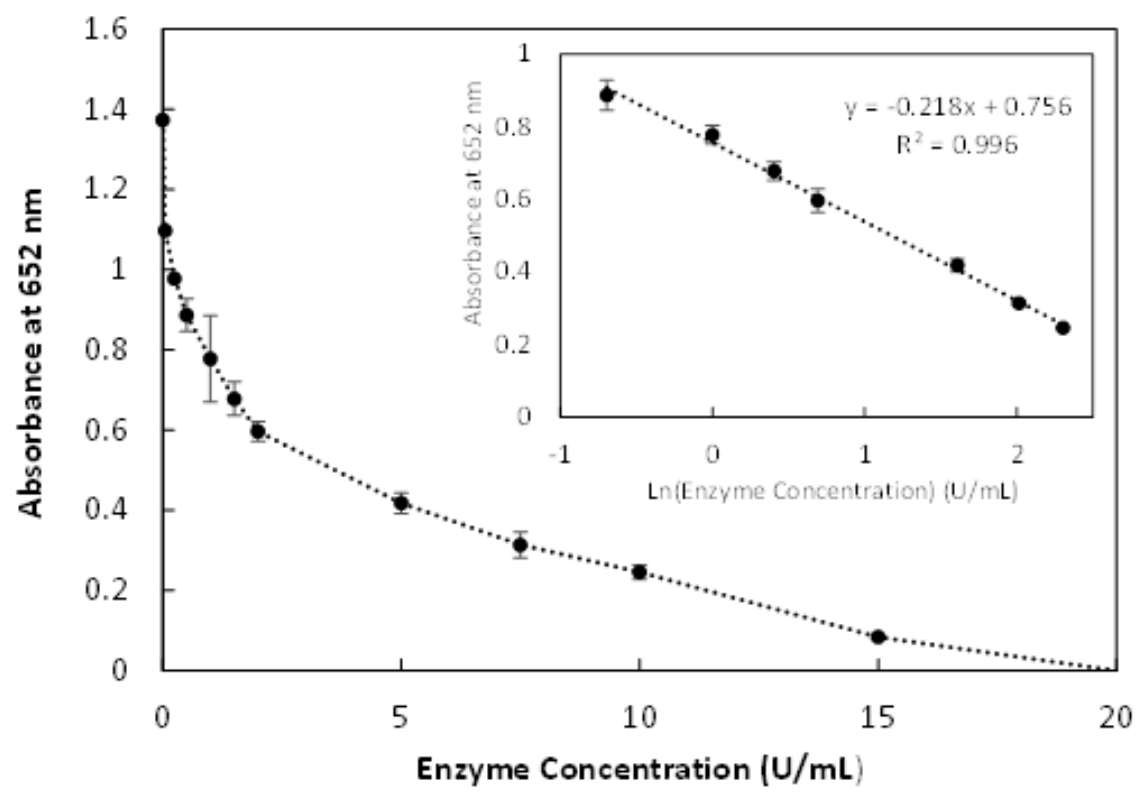

(C)

Fig. 3 


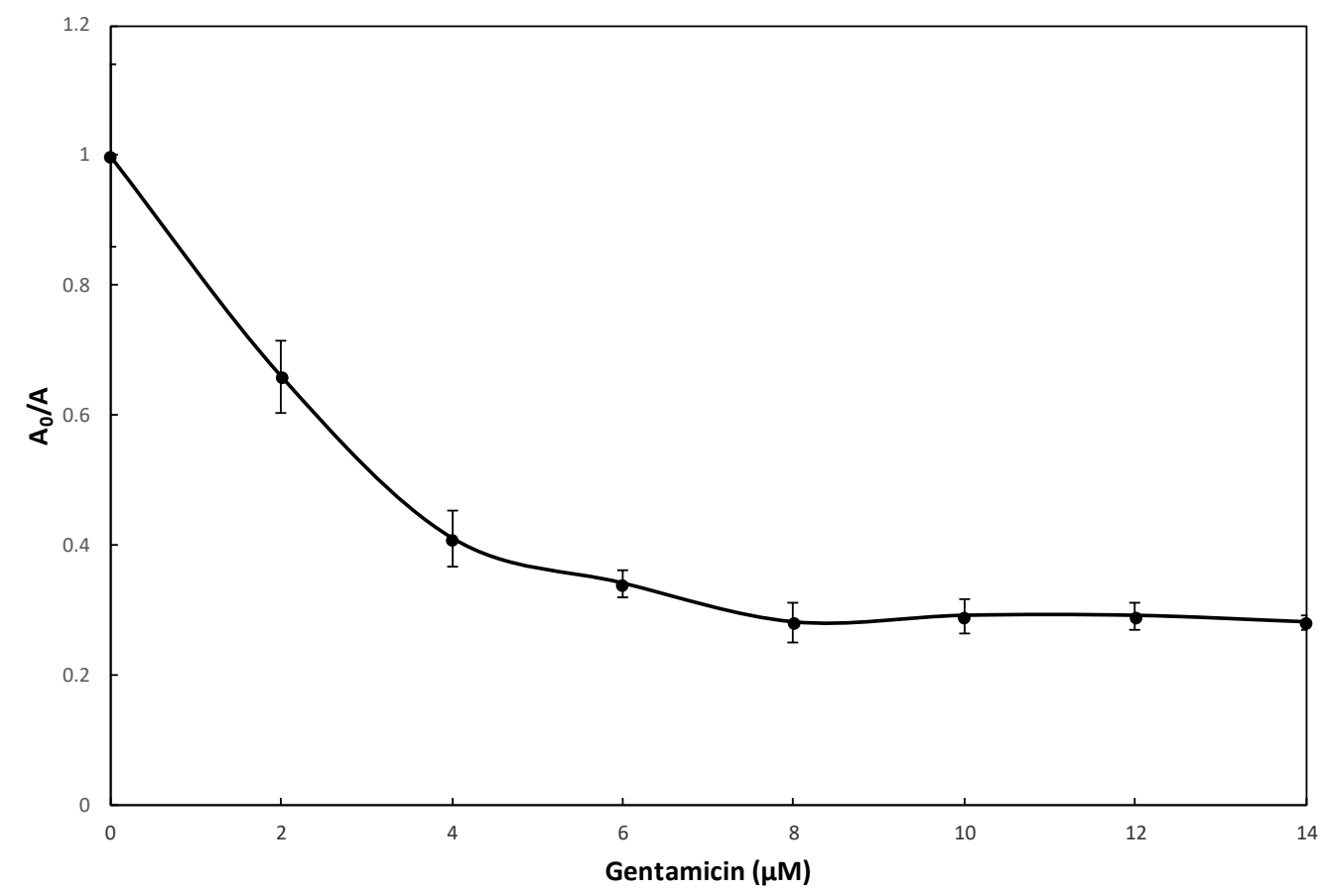

Fig. 4

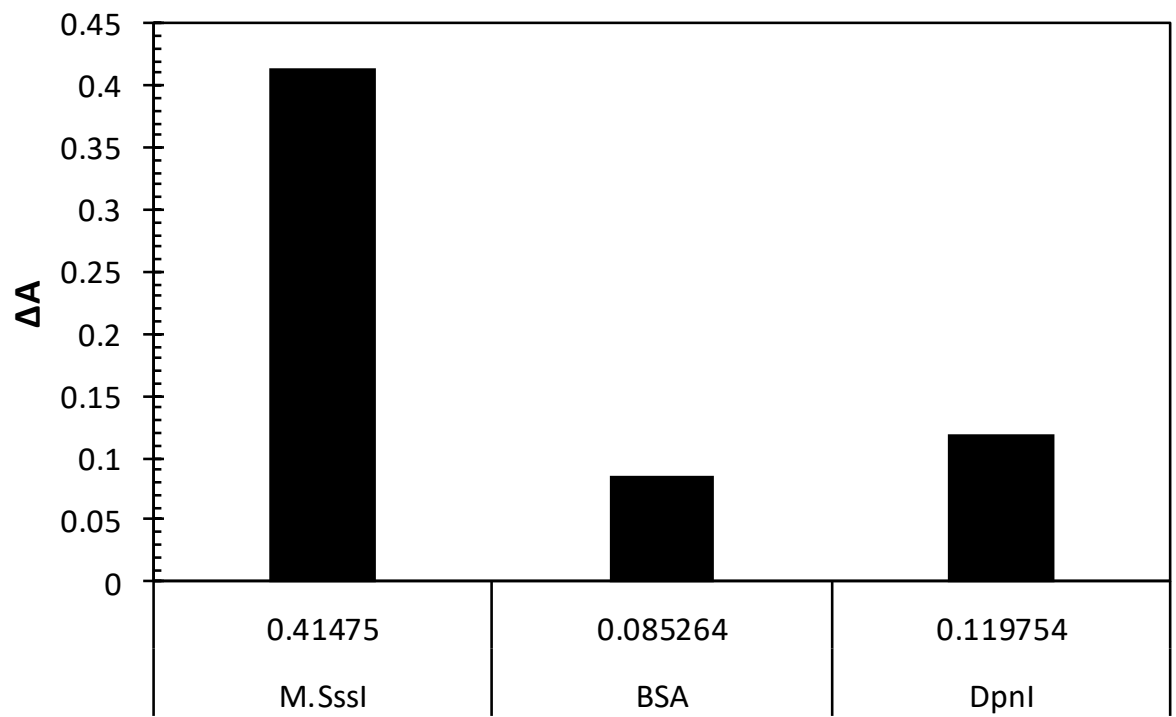


Fig. 5

\section{Supporting Information}

\section{Title: Colorimetric Detection of DNA Methyltransferase}

\section{Activity Based on Peroxidase Mimicking of DNA-Ag/Pt}

\section{Nanoclusters}

Hanie Ahmadzade Kermania ${ }^{a}$, Morteza Hosseinia, ${ }^{a, *}$, Andrea Miti ${ }^{b}$, Mehdi dadmehr ${ }^{c}$, Giampaolo Zuccheri $^{\text {b }}$, Saman Hossinkhani ${ }^{\mathrm{d}}$, Mohammad Reza Ganjalie,f 
${ }^{a}$ Department of Life Science Engineering, Faculty of New Sciences \& Technologies, University of Tehran, Tehran, Iran

${ }^{b}$ Department of Pharmacy and Biotechnology and Interdepartmental Center for Industrial Research on Health Sciences and Technologies at the University of Bologna, the Nanoscience Institute of CNR, the National Interuniversity Consortium of Materials Science and Technology. Via Irnerio, 48 Bologna, Italy 40126.

${ }^{c}$ Department of Biotechnology, Payeme Noor University, Tehran, Iran

${ }^{d}$ Department of Biochemistry, Tarbiat Modares University, Tehran, Iran

${ }^{e}$ Center of Excellence in Electrochemistry, School of Chemistry, College of Science, University of

Tehran, Tehran, Iran

${ }^{f}$ Biosensor Research Center, Endocrinology and Metabolism Molecular-Cellular Sciences Institute, Tehran University of Medical Sciences, Tehran, Iran

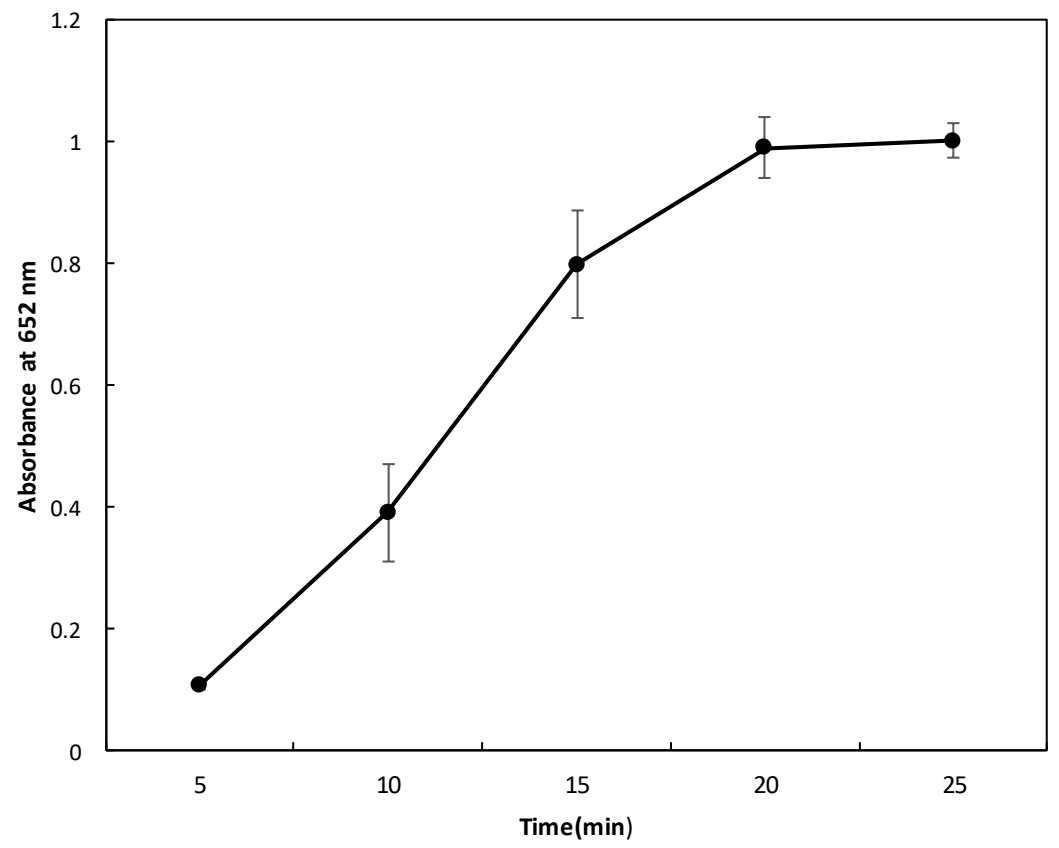

Fig. S1 Reaction time of DNA- $\mathrm{Ag} / \mathrm{Pt} \mathrm{NCs}$ in $\mathrm{TMB} / \mathrm{H}_{2} \mathrm{O}_{2}$ system. Condition: DNA-Ag/Pt NCs $(10 \mu \mathrm{l})$, Acetate buffer (200 mM ) - $\mathrm{pH} 4.0, \mathrm{H}_{2} \mathrm{O}_{2}(0.5 \mathrm{M})$ and TMB $(4 \mathrm{mM})$

E-mail address: smhosseini@ khayam.ut.ac.ir 


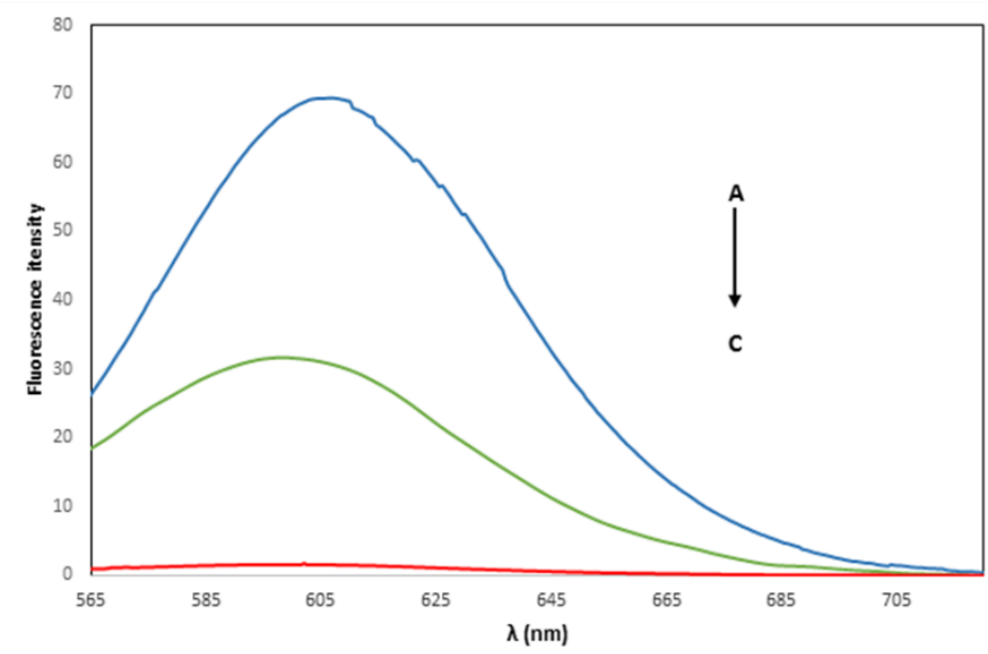

Fig. S2 Fluorescence spectra of DNA/AgNCs with(A) unmethylated, (B) methylated and (C) DNA$\mathrm{Ag} / \mathrm{Pt} \mathrm{NCs}$

\section{Characterization of DNA-Ag/Pt NCs}

Preliminary experiments have been performed on single stranded DNA sequences. The obtained DNA-Ag/Pt NCs display peroxidase-like catalytic activity and can effectively catalyze $\mathrm{H}_{2} \mathrm{O}_{2}$ mediated oxidation of TMB. Formation of $\mathrm{Ag} / \mathrm{Pt} \mathrm{NCs}$ is preferential on C-rich DNA templates and it should be less effective using a C-poor DNA sequences. In this regard, following identical procedures, we replaced the template DNA by a non C-rich random oligonucleotide, sequence S5 and not relevant catalytic activity was observed (Fig. 3SA). Moreover, to prove the feasibility of the proposed methylation detection method, the synthetically methylated version of $\mathrm{S} 1$, S3, has been tested for catalytic activity and a decrease in the absorbance of oxidized TMB was observed (Fig. 3SA and B). 


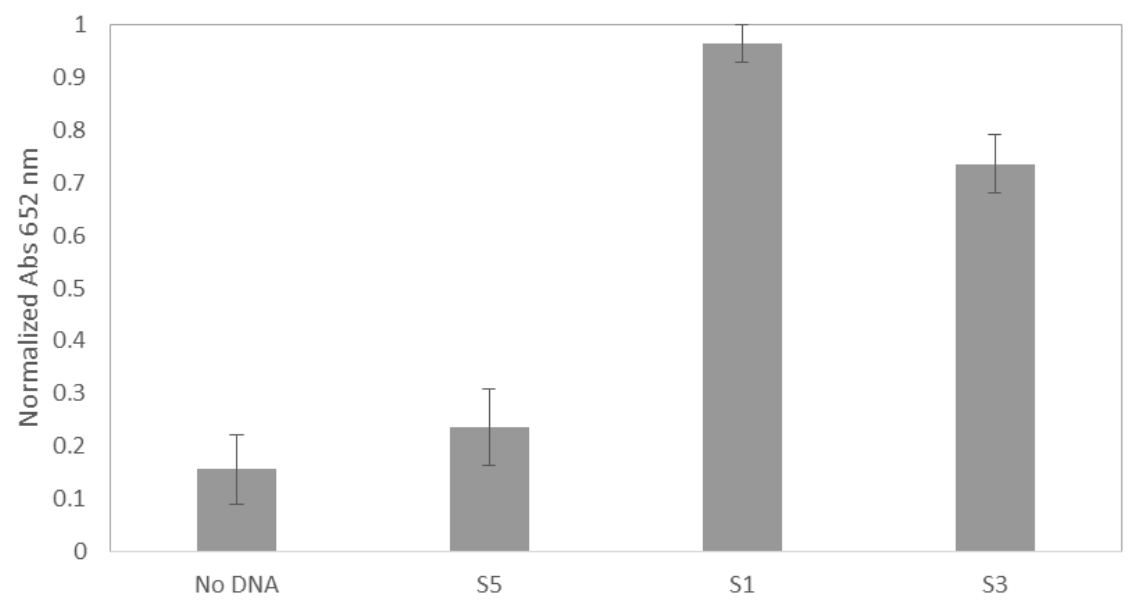

(A)

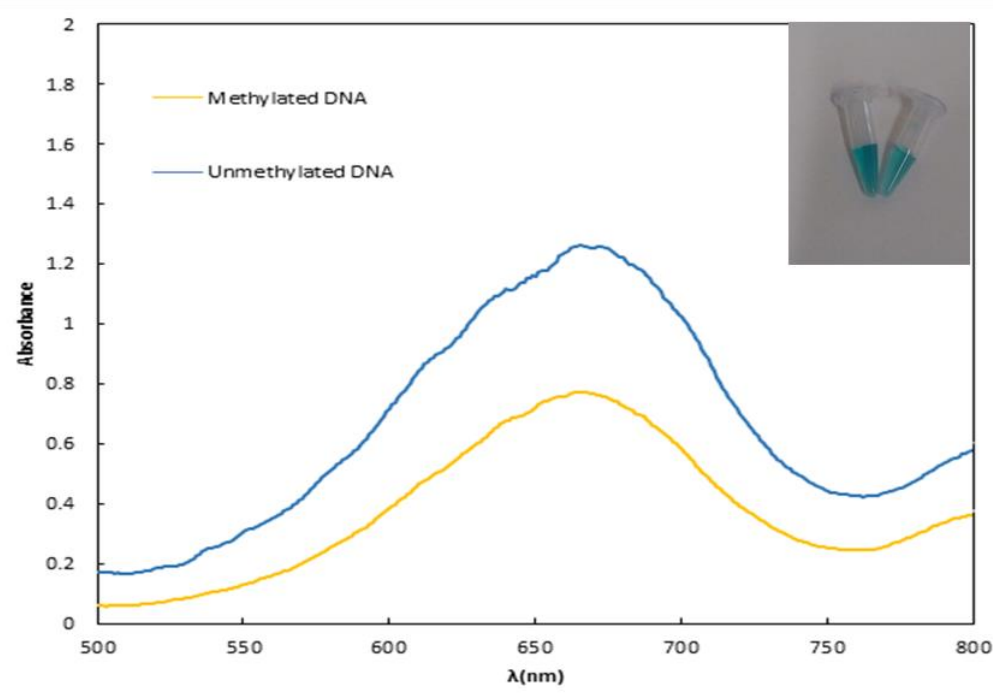

(B)

Fig. 3S (A) Absorbance at $652 \mathrm{~nm}$, corresponding to TMB oxidation, normalized for the absorbance at 652 of S4, showing highest catalytic activity. Standard deviation is depicted. S1: elected C-rich sequence for M.SssI detection; S3: methylated S1; S5: not C-rich DNA template; No DNA: control sample without DNA, submitted to the protocol for the formation of nanoclusters. Error bars show standard deviation for 3 experiments. (B) Not normalized absorbance spectra of DNA-Ag/Pt NCs showing oxidized TMB absorbance for methylated and unmethylated DNA.

In order to understand the phenomenon and the effect of methylation on the process, efforts have been made to characterize the DNA-Ag/Pt NCs. Gel electrophoresis analyses of the samples have 
been performed before and after the formation of nanoclusters, and in parallel with untreated DNA samples, to detect any difference in migration in the gel. PAGE electrophoresis analysis of DNA$\mathrm{Ag} / \mathrm{Pt}$ NCs showed the presence of a slightly lower intensity band below the oligonucleotide band for samples treated for nanoclusters formation. The presence of the lower band is matched to a decrease of intensity in the main band, suggesting the involvement of the same DNA (Fig 4S.A).

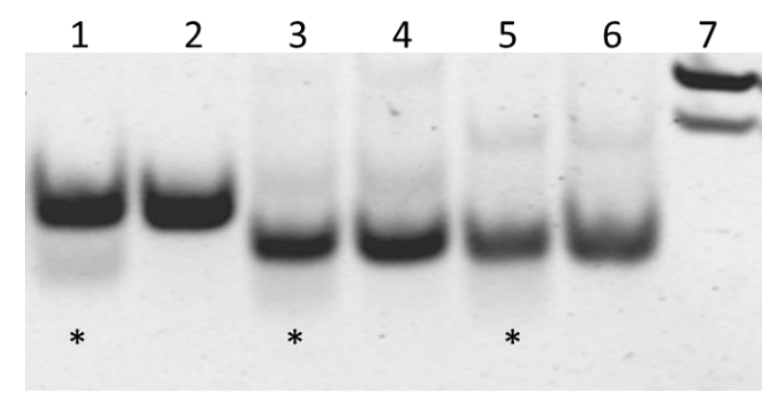

(A)

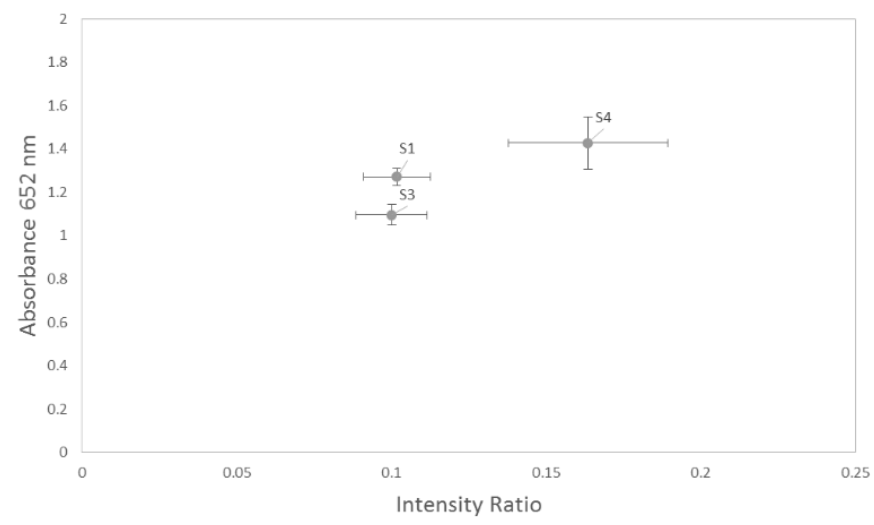

(B)

Fig. 4S (A) Sections of electrophoresis gel showing the samples with nanoclusters and control DNA with no nanoclusters. Lane 1, 3, 5, corresponds to DNA-Ag/Pt NCs respectively for S4 (C-rich control) S 3 and S1. Lanes 2, 4, 6 correspond to control DNA kept in same experimental and dilution conditions in absence of reagents for NCs formation. Lane 7, molecular weight marker. (B) Correlation between Intensity ratio calculated from densitometric measurements and catalytic activity of DNA-Ag/Pt NCs on templates S1, S3 and S4.

Gel-electrophoresis densitometric analysis let us estimate the ratio in the intensity between the main DNA band and new faster-migrating band in DNA-Ag/Pt NCs specimens. Non-obvious differences 
between methylated and unmethylated samples were found, but, interestingly, the control C-rich sequence S4, showing a higher catalytic activity, also showed a higher intensity ratio (Fig. 4SB). This seems to confirm that the new band observed in gel electrophoresis could be correlated to nanoclusters formation and to their catalytic activity. The observed distinct band is hardly due to DNA degradation, because a more irregular and less clear smearing would be expected, but likely to a change in oligonucleotide conformation leading to a faster migration of the DNA. It is possible that a different conformation occurs when the sequences interact with the formed nanoclusters. From gel analysis, it would derive that just a fraction of the DNA molecules has nanoclusters on them and those few could be guaranteeing the observed catalytic activity. Alternatively, it would also be possible that the nanoclusters are in equilibrium in their bound and unbound forms and that consequently just a small portion of DNA has an alternative electrophoretic mobility. Since DNA methylation does not affect the migration in gel, it does not presumably involve different oligonucleotides structures, but could affect such binding-unbinding equilibrium, if present, or just the catalytic activity.

Spectrophotometric analysis of DNA-Ag/Pt NCs has been performed for further characterization (Fig 5S). A low increase of absorbance, when compared to buffer, is observed in treated samples without DNA, probably because of the weak formation of metallic nanoclusters or nanoparticles in the reaction mixture in absence of DNA. A higher increase of absorbance is observed in the same region for DNA-Ag/Pt NCs samples: higher when compared to DNA controls and control without DNA (Fig. 5SA).

Subtracting the DNA spectra from the DNA-Ag/Pt NCs spectra (using spectra of DNA samples kept in the same experimental conditions and dilution) the contribution of DNA to the entire absorbance spectrum is reasonably removed. In Fig. 5SB, the differences of the normalized spectra for sequence S1, S2 and S4 DNA-Ag/Pt NCs are shown. Interestingly, unmethylated samples showed a small peak of absorbance closer to $300 \mathrm{~nm}$ while methylated DNA sequence S3 showed a closer to $280 \mathrm{~nm}$. It is also interesting to note that DNA-Ag/Pt NCs made on S4, showing a more intense peak at $300 \mathrm{~nm}$ 
are also the most catalytically active. Even if the identity of this peak is not clear, the wavelength range corresponds to the region where Pt nanoparticles and clusters could be expected.

In summary, according to our observations, the formation of $\mathrm{Ag} / \mathrm{Pt} \mathrm{NCs}$ probably leads to a change in the DNA conformation, not necessarily changed by the methylation of DNA. It is reasonable to think that different sequences could have different effects on the formation of nanoclusters and on their catalytic activity. We can see that the control sequence S4 shows higher intensity ratio in the densitometric analyses of the electrophoresis gels images, and the difference in spectra shows an absorbance peak at about $300 \mathrm{~nm}$, which could be related to the higher catalytic activity of these nanoclusters. Since, as shown, S1 DNA Ag/Pt NCs showed similar behavior in absorbance, the methylation of DNA could affect the interaction between DNA and formed nanoclusters, related to the shift in the peak observed at about $300 \mathrm{~nm}$.

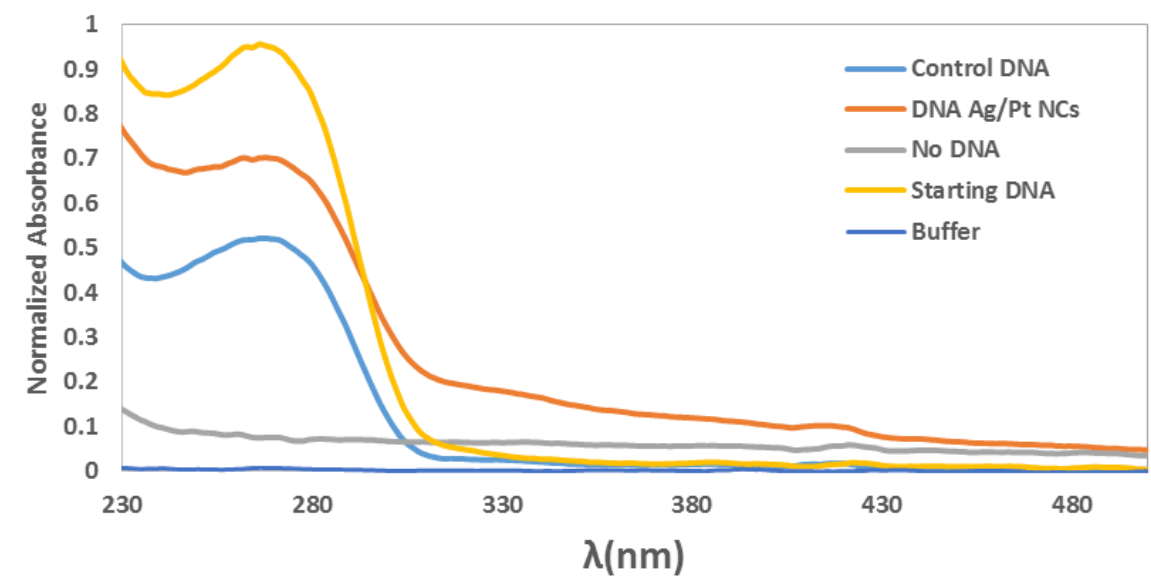

(A) 


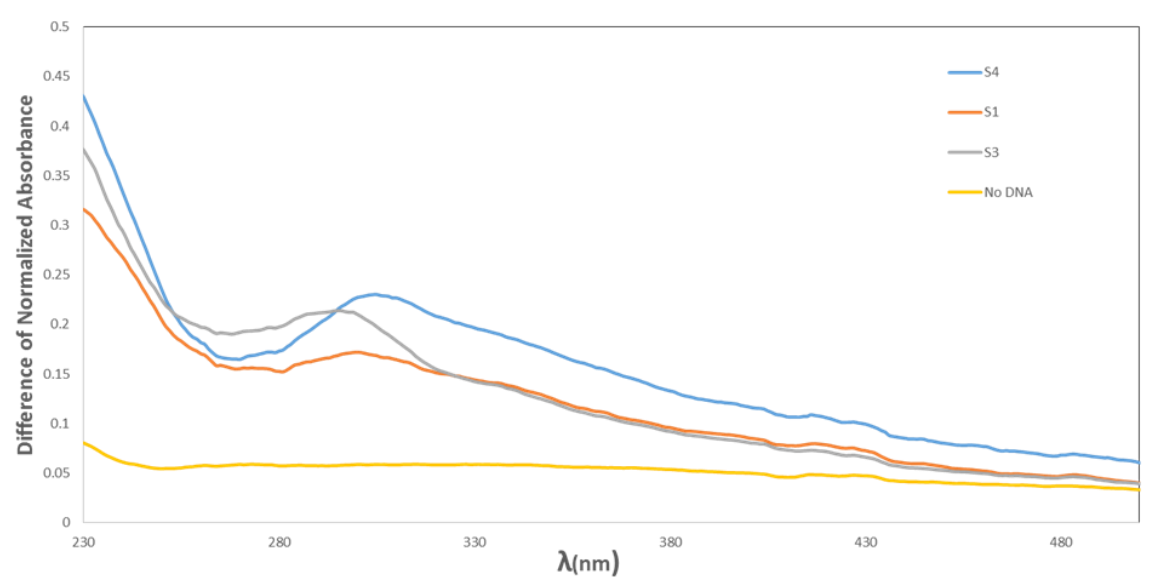

(B)

Fig. 5S (A) Normalized spectra relative to S1 sequence. (B) Difference between normalized spectra, obtaining subtracting the spectra of DNA control samples to DNA Ag/Pt NCs spectra.

Table S1 Sequences of Oligonucleotides Used in This Work

\begin{tabular}{ll}
\hline Name & Sequences $\left(5^{\prime}-3^{\prime}\right)$ \\
\hline S1 & CGCGCCCCTAATCCCCCGCG \\
S2 & GCGCGGGGATTAGGGGGCGC \\
S3 & C $\left(\mathrm{CH}_{3}\right) \mathrm{GC}\left(\mathrm{CH}_{3}\right) \mathrm{GC}\left(\mathrm{CH}_{3}\right) \mathrm{CCCTAATCCCCC}\left(\mathrm{CH}_{3}\right) \mathrm{GC}\left(\mathrm{CH}_{3}\right) \mathrm{G}$ \\
S4 & TCCTGGTCCGAGCTGCCCCGAG \\
S5 & GGAAGAGAAAGCGAGGTAGTGG \\
\hline
\end{tabular}

